\title{
RELEASE OF OXYTOCIN ELICITED BY SUCKLING STIMULUS IN MARES
}

\author{
O. P. SHARMA \\ Department of Veterinary Science, University of Kentucky, \\ Lexington, Kentucky 40506, U.S.A.
}

(Received 2nd October 1973)

The neurohypophysial hormone, oxytocin, is released in response to both external and internal neural stimuli. There is considerable published evidence indicating that release of oxytocin is elicited by the suckling or milking stimulus in the cow (Folley \& Knaggs, 1965; Hays \& Pritchard, 1967), the goat (Hawker \& Roberts, 1957), and the sheep (Fitzpatrick, 1961). There is no published report on the release of oxytocin during suckling in mares, however, and this communication presents the results of the effect of a suckling stimulus on the release of oxytocin in a lactating mare.

The effect of a suckling stimulus was examined in eight mares, all of which were studied less than 1 month after parturition. Foals were isolated from their dams for a period of 5 to $10 \mathrm{hr}$. A blood sample collected $15 \mathrm{~min}$ before initiation of nursing served as a control. Further blood samples were collected at $30 \mathrm{sec}$, and $1,2,3,4,5,10,15$ and 20 min after suckling. The foal was allowed to suck for the initial $3 \mathrm{~min}$. Approximately $10 \mathrm{ml}$ blood was collected in a heparinized tube at each time interval and the plasma was separated and frozen at $-19^{\circ} \mathrm{C}$ within 50 min of blood collection. The frozen plasma samples were thawed, equilibrated at $5^{\circ} \mathrm{C}$ and assayed for oxytocin by the technique of Van Dongen \& Hays (1964).

In seven of the eight mares tested, the control sample contained no detectable oxytocic activity (OA), but $\mathrm{OA}$ of the order of $1.03 \times 10^{-6}$ i.u./ml was present in Mare 5. In all mares tested, the sample collected $30 \mathrm{sec}$ after the initiation of nursing showed an abrupt increase in OA to amounts of the order of $1.25 \times 10^{-4}$ and $1 \times 10^{-3}$ i.u./ml (Mares 3, 6 and 8). The concentration at $30 \mathrm{sec}$ after the initiation of nursing was the peak OA for their entire series of blood samples. The peak OA $\left(1.1 \times 10^{-2}\right.$ to $1 \times 10^{-4}$ i.u. $\left./ \mathrm{ml}\right)$ in all mares occurred within the first $5 \mathrm{~min}$ after the initiation of nursing (Table 1). Once the peak was obtained, a decline of $\mathrm{OA}$ occurred. In no case, however, was there a complete absence of OA at the end of the 20 min of serial sampling (Text-figs 1 and 2). In Mares 3,7 and 6 , a second $\mathrm{OA}$ peak appeared $15 \mathrm{~min}$ after the initiation of nursing (Text-fig. 2). Owing to this, the pattern of OA decline in these mares was unlike that observed in other mares. At least in Mare 6, the second peak may be explained by the fact that the mare could no longer be restrained at 12 min and the foal again began to suck, causing the second peak. The OA in the control sample of Mare 5 may be due to some other unknown factor. Since all samples collected 20 min after the start of nursing showed OA, it is difficult 
Table 1. Concentration of oxytocic activity in mares at indicated times after the initiation of nursing

\begin{tabular}{c|c|l|c}
\hline $\begin{array}{c}\text { Mare } \\
\text { no. }\end{array}$ & $\begin{array}{c}\text { OA 30 sec after } \\
\text { initiation of nursing }\end{array}$ & \multicolumn{1}{|c|}{ Peak $O A$} & $\begin{array}{c}\text { OA 20 min after } \\
\text { initiation of nursing }\end{array}$ \\
\hline 1 & $1.03 \times 10^{-6}$ & $1 \times 10^{-4} 3 \mathrm{~min}$ & $1.06 \times 10^{-8}$ \\
2 & $1.08 \times 10^{-4}$ & $1.1 \times 10^{-2} 1 \mathrm{~min}$ & $1.02 \times 10^{-8}$ \\
3 & $1.25 \times 10^{-4}$ & $1.25 \times 10^{-4} 1-3 \mathrm{~min}$ & $1.08 \times 10^{-5}$ \\
4 & $1.05 \times 10^{-6}$ & $1.1 \times 10^{-4} 4 \mathrm{~min}$ & $1 \times 10^{-7}$ \\
5 & $1.03 \times 10^{-3}$ & $1.36 \times 10^{-3} 2 \mathrm{~min}$ & $1.07 \times 10^{-7}$ \\
6 & $1 \times 10^{-3}$ & $1 \times 10^{-3} 2,3,15 \mathrm{~min}$ & $1 \times 10^{-6}$ \\
7 & $1.02 \times 10^{-5}$ & $1.21 \times 10^{-4} 2 \mathrm{~min}$ & $1.14 \times 10^{-7}$ \\
8 & $1 \times 10^{-2}$ & $1.1 \times 10^{-2} 1 \mathrm{~min}$ & $1.02 \times 10^{-8}$ \\
\hline
\end{tabular}

$\mathrm{OA}=$ oxytocic activity in i.u./ml blood plasma.

* OA 15-min concentration because 20-min sample was lost.

to state how long it would take to inactivate circulating levels of $\mathrm{OA}$ in a lactating mare.

The OA in the plasma of the mares ranged from $1.1 \times 10^{-2}$ to $1 \times 10^{-4}$ i.u./ $\mathrm{ml}$. Analogous results were also reported using the same bioassay technique in the cow, i.e. $1 \times 10^{-3}$ i.u. $/ \mathrm{ml}$ (Sybesma, 1968), and $1 \times 10^{-4}$ i.u. $/ \mathrm{ml}$ (Hays \& Pritchard, 1967). The bioassay technique used to quantify OA in the plasma samples has a very high sensitivity $\left(1 \times 10^{-9} \mathrm{i} . \mathrm{u} . / \mathrm{ml}\right)$ and is very specific. At very low concentrations, however, the technique is not very precise.

Results from the present study indicate that nursing elicits the release of oxytocin $\left(1 \times 10^{-2}\right.$ to $1 \times 10^{-4}$ i.u. $\left./ \mathrm{ml}\right)$ in mares and that a level of $1 \times 10^{-7}$ i.u./ml can be maintained for as long as $20 \mathrm{~min}$ after its release.

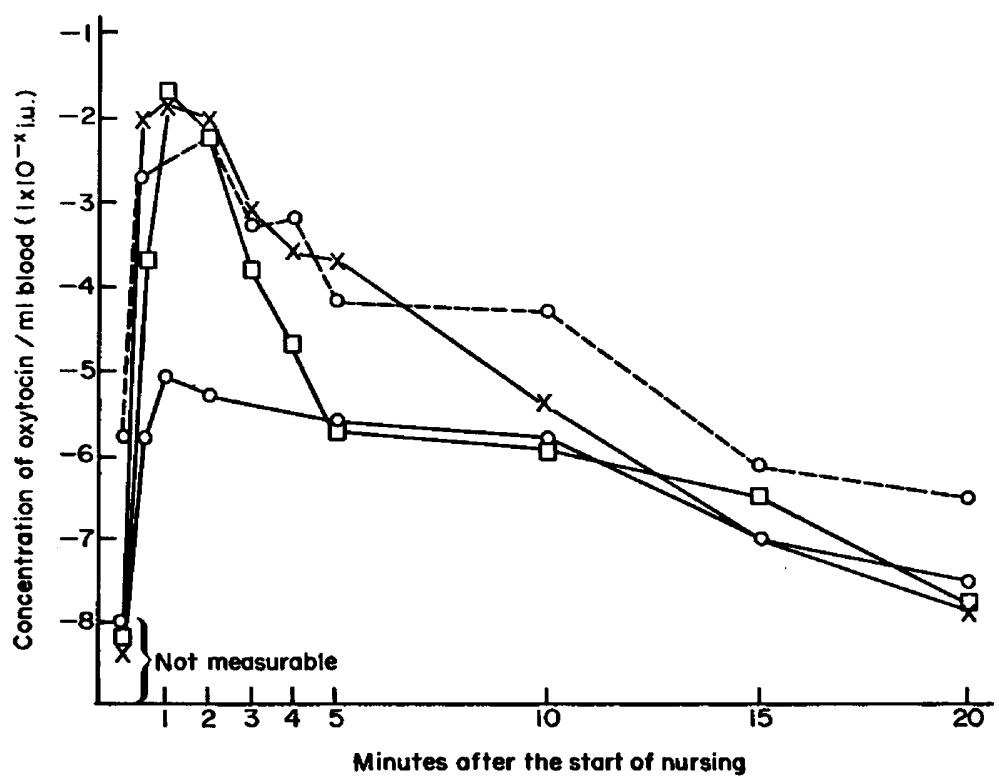

Text-FIG. 1. The amounts of oxytocic activity in Mares 5 ( $0-\ldots), 1(0-0)$, $8(x-x)$ and $2(\square-\square)$ at indicated time intervals after the initiation of nursing. 


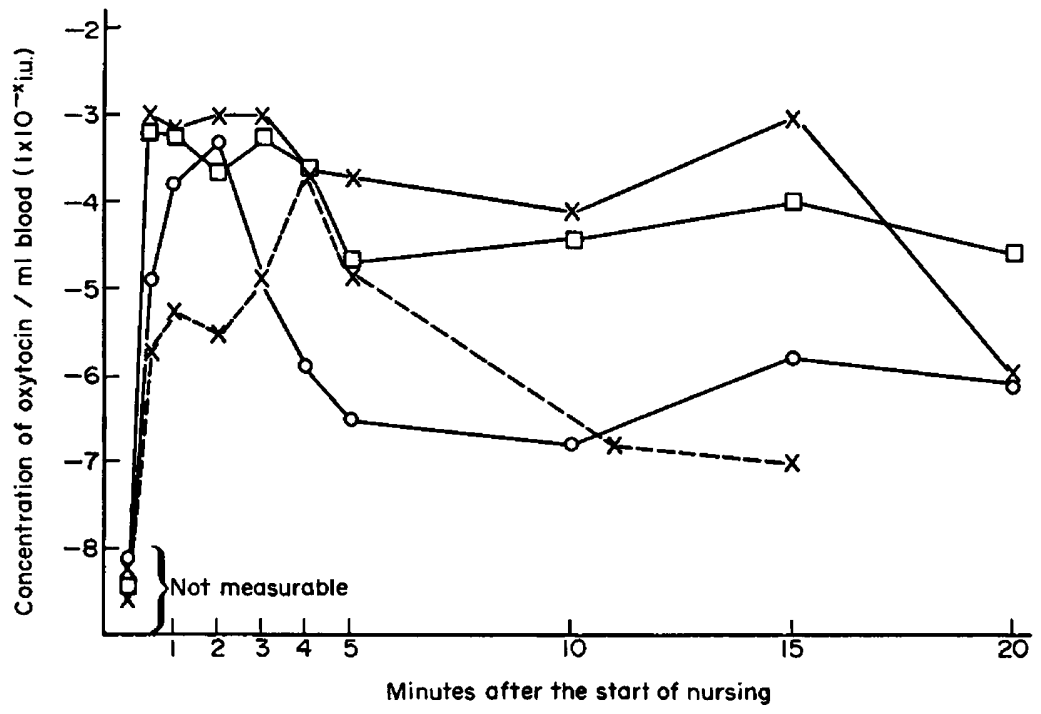

Text-pIG. 2. The amounts of oxytocic activity in Mares $7(0-0), 4(x-\cdots)$, $3(\square-\square)$ and $6(x-x)$ at indicated time intervals after the initiation of nursing.

The investigation reported in this paper is in connection with a project of the Kentucky Agricultural Experiment Station supported by a grant by The Grayson Foundation, Inc., and is published by the permission of the Director of the Station as Paper No. 73-4-114.

\section{REFERENCES}

FItZPATRICK, R. J. (1961) The estimation of small amounts of oxytocin in blood. In Oxytocin pp. 358-379. Eds. R. Galdeyro Bracia and H. Heller. Pergamon Press, Oxford.

FolLEY, S. J. \& KNAGgs, A. S. (1965) Oxytocin levels in the blood of ruminants with special reference to milking stimulus. In Advances in Oxytocin Research, p. 37. Pergamon Press, Oxford.

Hawker, R. W. \& Roberts, V. S. (1957) Oxytocin in lactating cows and goats. Brit. vet. J. 113, 459.

Hays, R. L. \& Pritchard, D. E. (1967) Oxytocin in the blood of cows during milking. Illinois Res. $9,16$.

Sybesma, W. (1968) Oxytocic activity measurements in blood plasma of cows and bulls. 6th Int. Congr. Anim. Reprod. EO A.I., Paris, $1,825$.

Van Dongen, G. G. \& Hays, R. L. (1964) A sensitive in vitro assay for oxytocin. Endocrinology, 78, 1. 